Annals of Plant Sciences

ISSN: 2287-688X

OPEN ACCESS

www.annalsofplantsciences.com

\title{
A Study on the proximate composition and nutritive value of local tree almonds, Prunus amygdalus
}

Pola Sudhakar ${ }^{*}$, Priyanka K. ${ }^{2}$, Angela E. Peter ${ }^{1}$, B. V. Sandeep ${ }^{1}$, M. Rajeswari2 ${ }^{2}$ B. Ganga Rao ${ }^{3}$, P. Sujatha 4

${ }^{1}$ Department of Biotechnology, College of Science \& Technology, Andhra University, Visakhapatnam, AP, India.

${ }^{2}$ Department of Food, Nutrition \& Dietetics, College of Science \& Technology, Andhra University, Visakhapatnam, AP, India.

${ }^{3}$ College of Pharmaceutical Sciences, Andhra University, Visakhapatnam, AP, India.

${ }^{4}$ Department of Biotechnology, Dr.B.R.Ambedkar University, Srikakulam, AP, India.

Received: 29-04-2018; Revised: 15-05-2018; Accepted: 27-05-2018

\begin{abstract}
Tree nuts form an essential part of our diet. They are rich in proteins, fats and an array of micro and macronutrients and are also palatable and considered as a delicacy. Among all the tree nuts, the almond is often referred to as the king of nuts. This is because it contains high amounts of nutritive elements like monounsaturated fatty acids, minerals such as magnesium and copper, $\alpha$-tocopherol and fiber making it an integral part of the diet. Almonds are known to reduce oxidative stress, inflammation and the risk of cardiovascular diseases and diabetes. The present study endeavored to determine the proximate composition of locally available tree almonds, Prunus amygdalus. The moisture content, ash value, iron, phosphorous, calcium, protein, fat and fiber levels were estimated by standard protocols. The results obtained were then correlated with previously described studies. The findings of this study were in line with previous studies. Locally available $P$. amygdalus was found to be a rich source of protein, fat, calcium and phosphorous. The moisture and ash content were low. The fiber content is moderate and amount of iron is considerably low. This makes locally available almonds a suitable, accessible and vital part of the diet.
\end{abstract}

Keywords: Prunus amygdalus, proximate composition, almonds, nutritive value

\section{Introduction}

Plant seeds constitute an essential part of human diet. Seeds serve as an excellent source for proteins, essential oils and fats and important micronutrients. While cereals and pulses represent seeds which are staple foods, tree nuts are the seeds that make up the auxiliary component of the diet. The use of nuts as auxiliary foods dates back to pre-agricultural times. An explosion of scientific studies on the merits of these nuts has served to advance their importance. This has led to the development of cutting-edge agricultural technologies for mass cultivation and processing due to the increasing demand for consumption.

Almonds are one of the most important and well consumed tree nuts across the world. While it is an important food crop grown commercially, it is also grown as an orchid crop and as an avenue tree in many places. Though the almond tree is widely distributed in the different tropical, sub-tropical and temperate regions of the world today, it is originally native to the warmer parts of North America and Western Asia. Almonds are prunes belonging to the rose family known as Rosaceae.

The almond tree is a small deciduous tree that grows to a height of around 4-10 meters. The trunk at its thickest can go up to $30 \mathrm{~cm}$ in diameter. The young twigs that develop are green to begin with, but turn purplish on exposure to sunlight and later

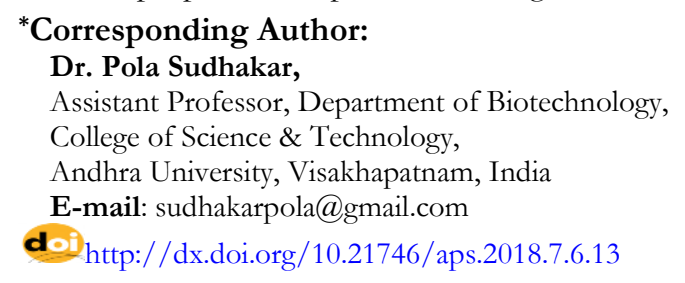

become grey after two years. The mature leaves are around 3-5 inches long with serrated margins and a 1 inch long petiole. The flowers of the almond tree are light pink or white, with 5 petals. Flowers appear in early spring, singly or in pairs, before leaves are produced. The almond tree can be considered as an economic crop only after a period of three years, which is when it actually begins to produce the nuts. The tree however reaches its full bearing status only after around 5-6 years of planting. Mature almonds are produced only 7-8 months post the flower formation, which is in autumn. In true botanical terms, the almond is not a nut but a drupe which is $3.5-6 \mathrm{~cm}$ long. The fruit is made up of four portions, a hard outer green shell called the hull, a middle hard shell, a thin brown leathery layer known as the skin of the almond and the seed or kernel which is inside.

Almonds or 'badam' as they are commonly referred to, in the commercial sense allude to the two edible parts among these four parts, the leathery skin and the kernel. They may be eaten blanched (with water or milk) or unblanched, raw or cooked/ roasted. Almonds are also used across a wide range of cuisines and for the preparation of various delicacies. They are used in the preparations of cakes and confectionary, in making sweets and chocolates, processed to develop butter and milk, known as almond butter and almond milk which is 
used in various preparations, ground in to a fine paste and added various dishes to enhance flavor and nutritive value and used for the extraction oil known as almond oil which is used in baking and for garnishing after cooking.
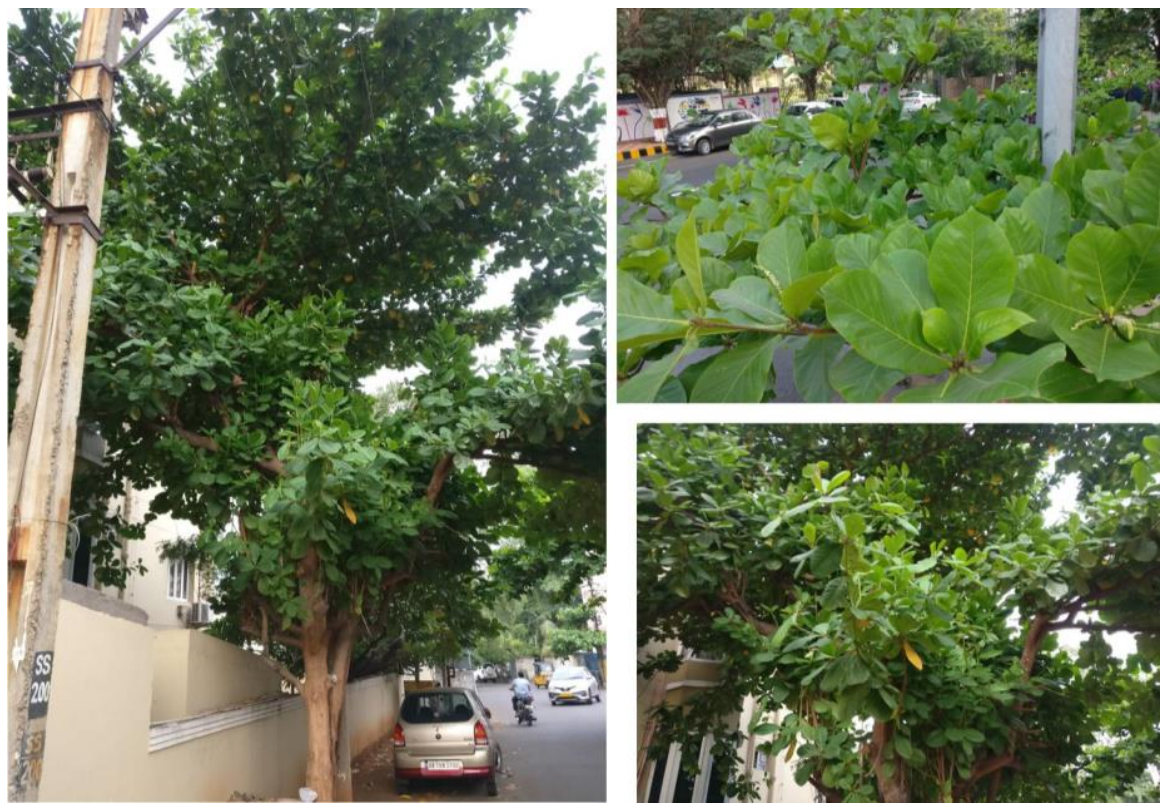

Figure 1. Local Almond Tree, Prunus amygdalus

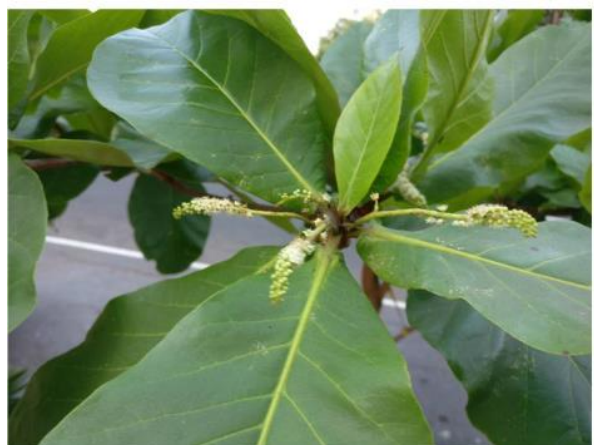

Figure 2. Inflorescence and Fruit of Prunus amygdalus

Almonds are a rich source of proteins, healthy fats, vitamins and minerals. It is essential in maintaining the vitality of the brain, strengthening muscles and improving muscle tone, reduces anemia and prolongs life. Given the above benefits and also being one of the most nutritive nuts, it is often called the king of nuts.

There are two types of almonds, sweet almonds and bitter almonds, the sweet almonds being more popular. The almond trees with pink flowers produce sweet almonds while those with white flowers give bitter almonds. The bitter almonds can be distinguished from the sweet ones as they are broader and shorter in appearance. Chemically too they differ, with the presence of a compound called amygdaline in the bitter almonds. As such, bitter almonds are not edible and are poisonous. This is because amygdaline on hydrolysis, yields glucose and the chemicals benzaldehyde and hydrocyanic

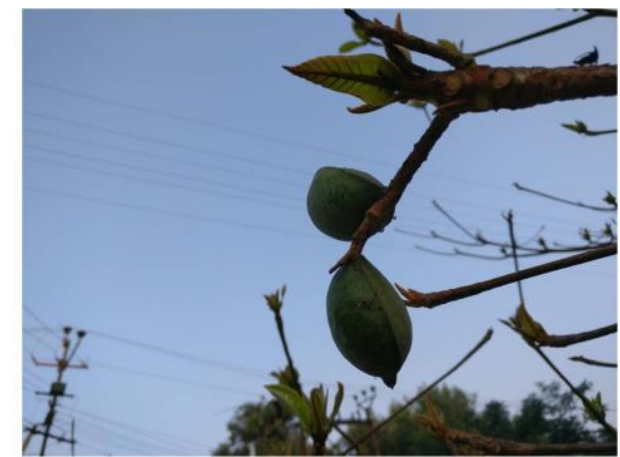

acid (HCN). This hydrocyanic acid is poisonous, the salt of it being cyanide. Bitter almonds yield 4-9 $\mathrm{mg}$ of hydrogen cyanide per almond (Hari and Lakshmi, 2012). However, they are primarily used in the preparation of oil which is used in herbal and ayurvedic medicine for disease cure and also for the production of flavor extracts which can be used for cooking or baking.

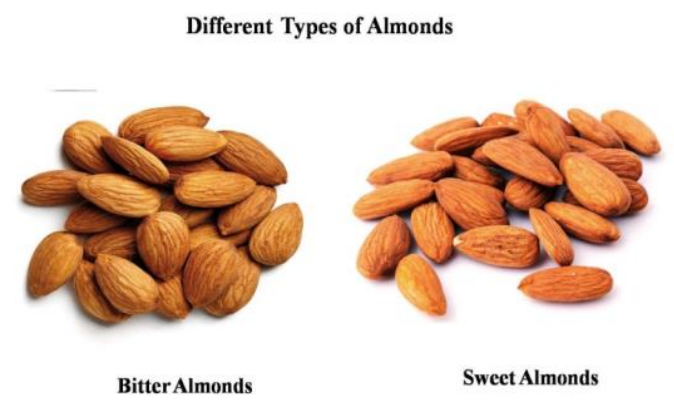

Figure 3. Bitter and Sweet Almonds 
Almonds are an excellent source of energy, as they typically contain around $575 \mathrm{kcal} / 100 \mathrm{~g}$. Though they contain about $50 \%$ fat, the amount of monounsaturated fatty acids (MUFA-62\%) dominates that of the polyunsaturated fatty acids (PUFA-24\%) and the saturated fat content is 3.7 $\mathrm{g} / 100 \mathrm{~g}$, which is the lowest of all nuts. Almonds are naturally low in sugars; the total sugar content is only $3.9 \mathrm{~g} / 100 \mathrm{~g}$. Almonds are a rich source of vitamin $\mathrm{E}$ and vitamin $\mathrm{B}_{2}$ (Richardson et al., 2009).

Table 1. Composition of Almonds

\begin{tabular}{|c|c|c|}
\hline Nutrients & Units & $\begin{array}{l}\text { Value per } 100 \mathrm{~g} \\
\text { Whole Almonds }\end{array}$ \\
\hline \multicolumn{3}{|l|}{ Proximates: } \\
\hline Calories & Kcal & 579 \\
\hline Water & G & 4.14 \\
\hline Protein & G & 21.15 \\
\hline Lipids (Total) & G & 49.93 \\
\hline Dietary Fiber (Total) & G & 12.5 \\
\hline Sugars (Total) & G & 4.35 \\
\hline Ash & G & 2.97 \\
\hline \multicolumn{3}{|l|}{ Minerals: } \\
\hline Calcium & $\mathrm{Mg}$ & 269 \\
\hline Iron & $\mathrm{Mg}$ & 3.71 \\
\hline Magnesium & $\mathrm{Mg}$ & 270 \\
\hline Phosphorous & $\mathrm{Mg}$ & 481 \\
\hline Potassium & $\mathrm{Mg}$ & 733 \\
\hline Sodium & $\mathrm{Mg}$ & 1 \\
\hline Zinc & $\mathrm{Mg}$ & 3.12 \\
\hline Copper & $\mathrm{Mg}$ & 1.03 \\
\hline Manganese & $\mathrm{Mg}$ & 2.18 \\
\hline \multicolumn{3}{|l|}{ Vitamins: } \\
\hline Vitamin E ( $\alpha$-tocopherol) & $\mathrm{Mg}$ & 25.63 \\
\hline Thiamin & $\mathrm{Mg}$ & 0.21 \\
\hline Niacin & $\mathrm{Mg}$ & 1.14 \\
\hline Riboflavin & $\mathrm{Mg}$ & 3.62 \\
\hline Pantothenic acid & $\mathrm{Mg}$ & 0.47 \\
\hline Vitamin B6 & $\mathrm{Mg}$ & 0.14 \\
\hline Folate, food & Mcg & 44 \\
\hline \multicolumn{3}{|l|}{ Fatty Acids: } \\
\hline Saturated (Total) & G & 3.80 \\
\hline 16:0 Palmitic & G & 3.08 \\
\hline 18:0 Stearic & G & 0.70 \\
\hline Monounsaturated (total) & G & 31.15 \\
\hline 16:1 Palmitoleic & G & 0.23 \\
\hline 18:1 Oleic & G & 31.29 \\
\hline Polyunsaturated (total) & G & 12.33 \\
\hline 18:2 Linoleic & G & 12.32 \\
\hline
\end{tabular}

The phytochemical composition of almonds has also been studied. The phytosterol content of almonds which was found to be $187 \mathrm{mg} / 100 \mathrm{~g}$ is considerably high. Although a low amount of carotenoids are found in almonds, they are not a major source of dietry carotenoids. The total phenol content of almonds was assessed to be 4.2 $\mathrm{mg} \mathrm{GAE} / \mathrm{g}$, which is moderate when compared to other nuts. Resveratrol was not found in almonds. The total flavanoid concentration of almonds is one of the highest among nuts, $15 \mathrm{mg} / 100 \mathrm{~g}$. It is of considerable interest to note that almonds can contribute total flavonoids to the diet in amounts equivalent to fruits, as they have a similar quantity of total flavonoids as red delicious apples at 15 and apricots at $13 \mathrm{mg} / 100 \mathrm{~g}$. The amount of proanthocyanidins in almonds is also high, 184 $\mathrm{mg} / 100 \mathrm{~g}$ (Oliver and Jeffrey, 2008).

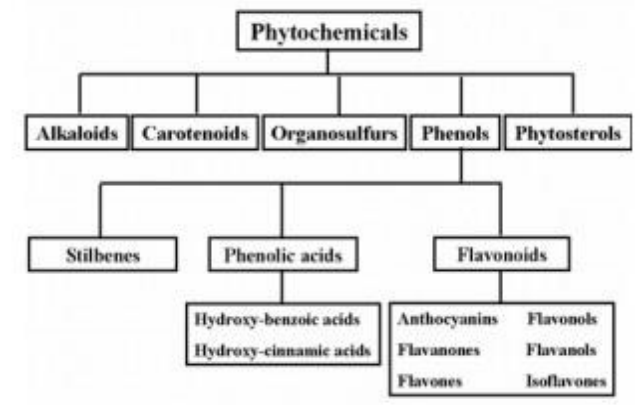

Figure 4. Different Phytochemicals responsible for Pharmacological Activities in Plants

The Oxygen Radical Absorbance Capacity (ORAC) of almond was found to be moderate, $45 \mu \mathrm{mol}$ TE/g as was the Ferric Reducing Antioxidant Power (FRAP), $41 \mu \mathrm{mol} \mathrm{Fe} \mathrm{Fe}^{+2} / \mathrm{g}$ (Oliver and Jeffrey, 2008). Defatted almond seeds were extracted with aqueous acetone and subjected to column chromatography. The two fractions obtained and the crude extract was assessed for Total Antioxidant Activity (TAA). One of the fractions was found to be rich in tannins, and it exhibited the highest TAA of $3.93 \mathrm{mmol}$ Trolox/g, while that of the crude extract was $0.24 \mu \mathrm{mol}$ Trolox $/ \mathrm{mg}$ and the other fraction TAA was $0.09 \mu \mathrm{mol}$ Trolox/mg (Ryszard et al., 2005). The antioxidant activity of whole almond seed, brown skin and green shell cover was also assayed, using different food model systems. While all three exhibited high antioxidant activity, it was observed that the method used determined which exhibited the highest, from some it was the green shell cover while for another, it was the seed (Subhashineeet al., 2006). The methanolic extract of almond hulls when assayed for antioxidant activity exhibited a higher activity than that of $\alpha$-tocopherol (Gray and Lan, 2003). On the whole it is certain that the almond exhibits antioxidant activity due to the presence of different phytochemicals it contains.

HPLC analysis of almond extracts revealed the presence of the following major phenolic acids, caffeic, ferulic, $p$-coumaric and sinapic acids (Subhashinee et al., 2006). Methanol extract of almond hulls were analyzed by HPLC and showed the presence of chlorogenic acid, cryptochlorogenic acid and neochlorogenic acid (Gray and Lan, 2003).

The presence of these different phytochemicals and an array of nutritive elements in almonds result in them possessing several important pharmacological activities. Several studies have shown an association between nut consumption and a reduced risk of CHD (Coronary Heart Disease). Consumption of almonds regularly on a daily basis was found to result in decreased levels of cholesterol and LDL (low-density lipoprotein) and an improvement in serum lipid profiles (Chen et al., 2006; Hari and Lakshmi, 2012). The hypoglycemic activity of almonds is because they have a low glycemic index 
and are rich in fiber, which results in appetite suppression due to increased satiety. Consumption of almonds was found to lower post-prandial glycaemia, insulinaemia and oxidative stress. Ethanolic extracts of almond leaves, flowers and seeds exhibited ability to lower blood glucose levels in streptozotocin-induced diabetic mice (Hari and Lakshmi, 2012). Almonds were found to possess immunostimulant activity, consumption of almonds resulted in high levels of cytokine production; interferon- $\alpha$ (INF- $\alpha$ ), interleukins (IL-12), INF- $\gamma$ and tumor necrosis factor (TNF- $\alpha$ ) (Adriana and Bisignano, 2010). A paste of almonds was found to reverse scopolamine-induced amnesia in rats, suggesting that almonds are a useful memoryrestorative agent (Kulkarni et al., 2010). The prebiotic activity of almonds has been studied. They are found to alter the composition of gut bacteria by stimulating the growth of bifid bacteria and Eubacterium rectale (Mandalari et al., 2008). Almonds also possess anticancer activity. An almond-based diet was found to activate antiproliferative signaling and reduce aberrant crypt foci in the gastrointestinal tract in rats (Davis and Iwahashi., 2001).

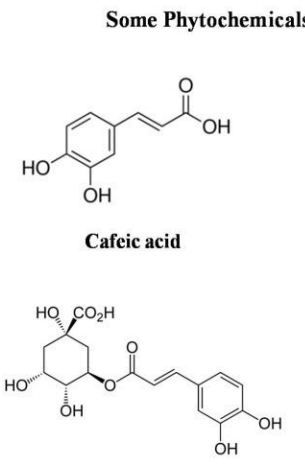

Chlorogenic acid<smiles>COc1cc(/C=C/C(=O)O)cc(OC)c1O</smiles>

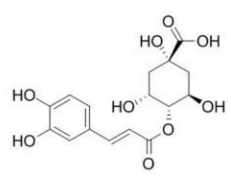

Cryptochlorogenic acid
Figure 5. Few Phytochemicals Found in Almonds

The consumption of nuts has been heralded as a healthy dietary habit. There are, however some instances of individuals being allergic to tree nuts, including almonds. This king if $\operatorname{IgE}$ mediated adverse allergic reactions is estimated to affect only $1-2 \%$ of the population. Methods have been developed to identify and detect amandin, the major storage protein of almonds (Sathe et al., 2002). In order to reduce this $\operatorname{IgE}$ binding activity of almond proteins, pre-treatment processes such as blanching and roasting can be performed before consumption (Venkatchalam et al., 2002).

\section{Materials and Methods}

Local almonds (Prunus amygdalus) were collected form Andhra University Ladies Hostel Campus during the month of December, 2016. The almonds were plucked from the trees along with their shell and were dried in the sunlight for one week post which the shell was removed to obtain the kernel.
Care was taken while removing the shell so that the sample is not damaged.

The almond kernels obtained were separated into two groups. For one group the seed coat was removed, while for the other the seed coat was left undisturbed. The samples of both groups was powdered in a blender for homogeneity and stored in air-tight containers at $-4^{\circ} \mathrm{C}$ until further use.

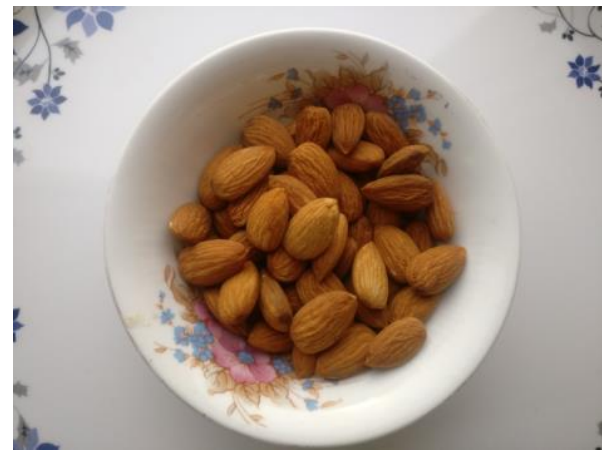

Figure 6. Locally collected Prunus amygdalus with Seed Coat

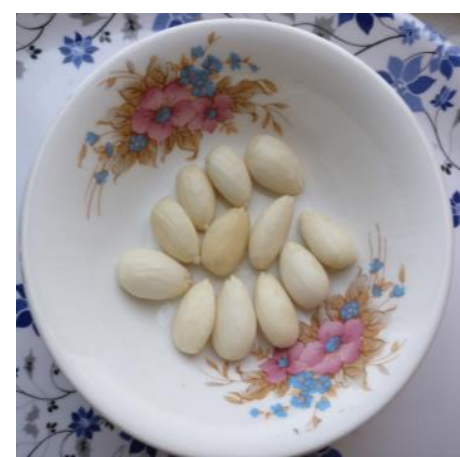

Figure 7. Seeds of P. amygdalus without Seed Coat

\section{Moisture:}

The moisture content of the samples was determined by the AOCS method. $5 \mathrm{~g}$ of test sample is taken in a dish container and dried in an oven at $130^{\circ} \mathrm{C}$ for 2 hours. The heated portion was then allowed to cool in a dessicator to room temperature and the loss of weight was determined.

\section{Ash:}

The ash content of the samples was determined by the AOCS method. Accurately weighed sample, of about $0.5 \mathrm{~g}$ is placed in a ceramic crucible (that is previously heated and cooled until constant weight is obtained) and then subjected to ashing at $550^{\circ} \mathrm{C}$ for about $12 \mathrm{~h}$ in a muffle furnace, and then ash content determined.

\section{Iron:}

The amount of iron in the samples is quantified calorimetrically, by Wong's method, 1928, that makes use of fact that ferric ion gives red colour with potassium thiocyanate. The intensity of red color is directly proportional to the iron present in the given sample and is measured at $540 \mathrm{~nm}$. 


\section{Phosphorous:}

The method described by Fiske and Subbarow, 1925 was used to determine the amount of phosphorous in the samples under study. This method uses ANSA (1-amino-2-naphthol-4sulphonic acid) and results in a blue color complex being formed, which can be measured colorimetrically at $660 \mathrm{~nm}$. Hence, color intensity is directly proportional to concentration of phosphorous.

\section{Calcium:}

The amount of calcium the almond samples is estimated by the procedure described by Raghu Ramulu et al., $1983.2 \mathrm{ml}$ of ash solution is adjusted to a suitable $\mathrm{pH}$ for the precipitation of Calcium. The treated solution is then titrated with $\mathrm{KMNO}_{4}$ in hot condition. The end point was noted which was definite pink color which persists for $1 \mathrm{~min}$.

\section{Protein:}

Lowry et al., 1951 method was employed to study the colorimetrically at $660 \mathrm{~nm}$. The intensity of the blue color produced depends upon the amount of the aromatic amino acids, which vary for different proteins.

\section{Crude fiber:}

The fiber content of the sample was determined by the exactly 30 minutes. After cooling, the solution is filtered and the filtrate was then washed into another flask using distilled water. The filtrate is then subjected to extraction with $1.25 \% \mathrm{NaOH}$ for 30 minutes. The same process is repeated with the acid and the alkali solutions alternatively for 4-6 times. After the final filtration process, the preweighed muslin cloth is dried and weighed with residue. The difference in the initial and final weights gives the amount of fiber in that particular quantity of the sample.

\section{Crude fat:}

The crude fat content in local almonds was estimated by the method given by Raghu Ramulu et al., 1983. Crude fat content is determined by extracting the fat from the sample using a suitable solvent, then determining the fat recovered. $10 \mathrm{~g}$ of the sample was subjected to extraction with $150 \mathrm{ml}$ of petroleum ether in a Soxhlet liquid/solid extractor. The extraction was continued for 6 hours, then the heat source was removed and the solvent drained from the extractor into the flask. The flask was replaced by the heat source to evaporate off the solvent. The flask was cooled and then weighed with its contents. Then the crude fat calculated from the recorded weights.

\section{Results and Discussion}

\section{Moisture content:}

The moisture content of locally collected tree almonds was determined by the AOCS method.
Both the samples; almonds with and without seed coat showed a relatively low moisture content as anticipated, being nuts. Among the two samples, the almonds without seed coat showed higher levels of moisture, $9.9 \mathrm{~g} / 100 \mathrm{~g}$ when compared to almonds with seed coat, having a moisture content of $6.4 \mathrm{~g} / 100 \mathrm{~g}$.

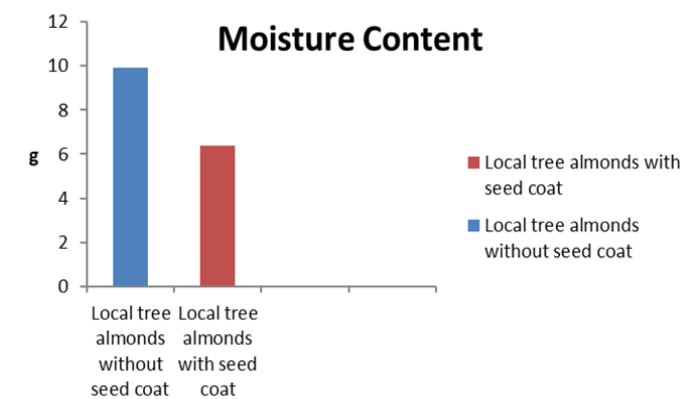

Figure 8. Moisture Content of locally collected Prunus amygdalus Seed

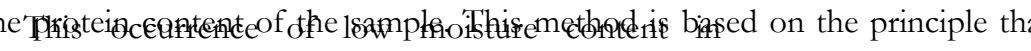
almonds is in line with several studies conducted on other different varieties of almonds. A study by Aslanta et al., 2001, on thirteen types of sweet almonds showed that the moisture content ranged from 3.60-4.39\%. Susan et al., 2005 found that the moisture content in three varieties of almonds from hecrar $4.33 \mathrm{~g} / 100 \mathrm{~g}$. A study on nine different varieties of almonds from Turkey also yielded similar results with low moisture content; ranging from 2.28$3.70 \%$ (Mikdat and Veysi, 2017). The milk extracted from blanched almonds were similar to values reported for melon seed milk $(88.0 \%)$ and cow milk (87.10\%) (Omole and Ighodaro, 2012). Seham et al., 2014 found that moisture content in kernel of $P$. amygdalus of the Middle East region is low, $4.37 \%$, which is important for an extended shelf life and sensory quality in nuts, as low moisture helps reduce microbial growth and various undesirable biochemical changes that often accompany it.

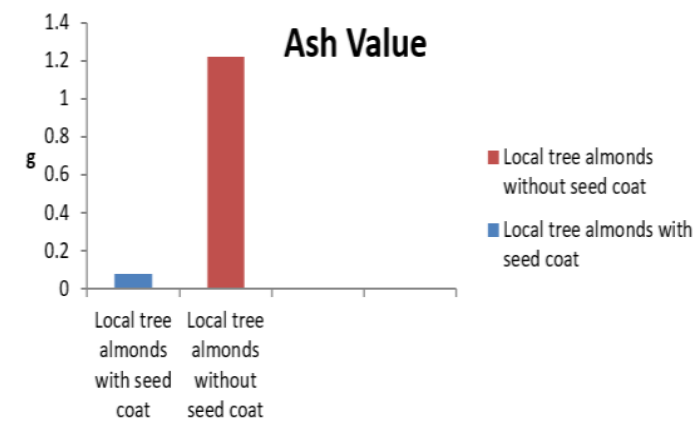

Figure 9. Ash value of $P$. amygdalus Seeds

Ash Value:

Estimation of ash value was done in the two samples of local tree almonds, with seedcoat and without seedcoat by the AOCS method. The 
ash content in almonds is very low, for almonds without seed coat it is $1.22 \mathrm{~g} / 100 \mathrm{~g}$ and for those with seed coat it is $0.08 \mathrm{~g} / 100 \mathrm{~g}$ in each sample.

Studies on ash value of different varieties of almonds from several regions of the world also revealed that the ash value in them is very low. Seham et al., 2014 reported a low ash content of $3.82 \%$ in almonds from the Middle East region. Nine varieties of almond kernels from Turkey were studied (with the seed coat), revealing ash value of 3.12-4.69\% (Mikdat and Veysi, 2017). Agunbiade and Olanlokun, 2006 studied the ash content on Indian variety of almonds ( $P$. amygdalus) growing in Nigeria, which was found to be a little higher when compared to that of other studies, $6.76 \%$. Studies on the almond kernel carried out by Ozcan et al., 2011 also revealed low ash content, ranging from $2.74-3.05 \%$. The ash content of three varieties of almond seeds $(P$. dulcis, with seed coat) was found to be 3.74 $4.56 \mathrm{~g} / 100 \mathrm{~g}$ (Susan et al., 2005).

\section{Iron:}

Iron is an indispensible component for every living organism. It is essential for the transport of oxygen, electron transfer and oxidation-reduction reactions in the body. Foods containing high amounts of iron are of great interest to the scientific community as the deficiency of iron is a persistent problem. The Recommended Dietary Allowance (RDA) for all age groups of men and postmenopausal women is 8 $\mathrm{mg} /$ day; the RDA for premenopausal women is 18 $\mathrm{mg} /$ day. The median dietary intake of iron is approximately 16 to $18 \mathrm{mg} /$ day for men and 12 $\mathrm{mg} /$ day for women. The amount of iron in the samples is quantified calorimetrically, by Wong's method, 1928. The iron content in the samples with seed coat is found as $6.25 \mathrm{mg} / 100 \mathrm{~g}$ and that without seed coat is $8.325 \mathrm{mg} / 100 \mathrm{~g}$.

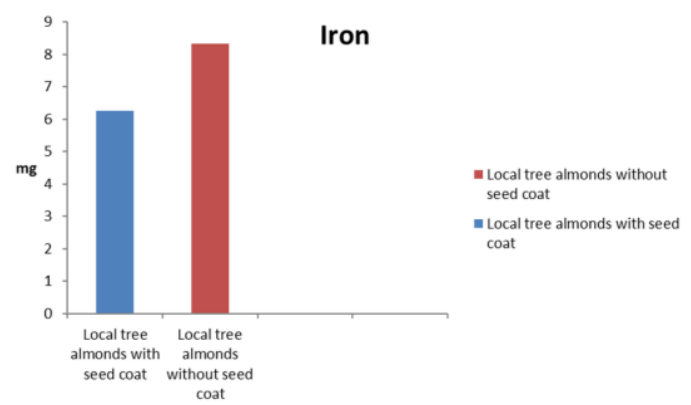

Figure 10. Iron Content of locally collected P.amygdalus Seeds

Mikdat and Veysi,. 2017 found that P. amygdalus contained trace amounts of iron; $5.39-10.28 \mathrm{mg} / 100 \mathrm{~g}$ in the nine genotypes studied. Saura and Cafiellas, 1982 reported the presence of $3.10-4.40 \mathrm{mg} / 100 \mathrm{~g}$ and $3.00-4.00$ $\mathrm{mg} / 100 \mathrm{~g}$ of iron in almond varieties. Iron was determined using Atomic Absorption Spectrophotometry for thirteen varieties of sweet almonds by Aslanta et al., 2001. The amount of iron ranged from $54.13-146.35 \mathrm{ppm}$ for the different varieties. The amount of iron found in almond milk extract was 1.40 $\mathrm{mg} / 100 \mathrm{ml}$, which was found to be higher than that of soy milk $(0.58 \mathrm{mg} / 100 \mathrm{ml})$ and dairy milk (0.1-0.3 mg/100ml) (Alozie et al., 2015; Potter, Hotchkiss, 1995; Passmore, Eastwood, 1986). Nigerian grown Indian almonds showed possessed an iron content of $70.62 \mathrm{ppm}$ (Agunbiade and Olanlokun, 2006). The iron content of $P$. amygdalus from Middle East regions was found to be $119.9 \mathrm{mg} / \mathrm{kg}$ (Seham et al., 2014).

\section{Phosphorous:}

Phosphorous is a macronutrient that is a prerequisite for several biological processes, like protein phosphorylation, DNA synthesis, Membrane synthesis and ATP synthesis. It is also essential for the formation of teeth and bones. The Recommended Dietary Allowance (RDA) of phosphorus is $700 \mathrm{mg} /$ day. The method described by Fiske and Subbarow, 1925 was used to determine the amount of phosphorous in the samples. Locally collected P. amygdalus was found to contain considerable amount of phosphorous. There was not much difference in the phosphorous content in both the almond samples; with and without seed coat. Almonds without seed coat contained $135 \mathrm{mg} / 100 \mathrm{~g}$ while those with seed coat had 133.25 $\mathrm{mg} / 100 \mathrm{~g}$ phosphorus.

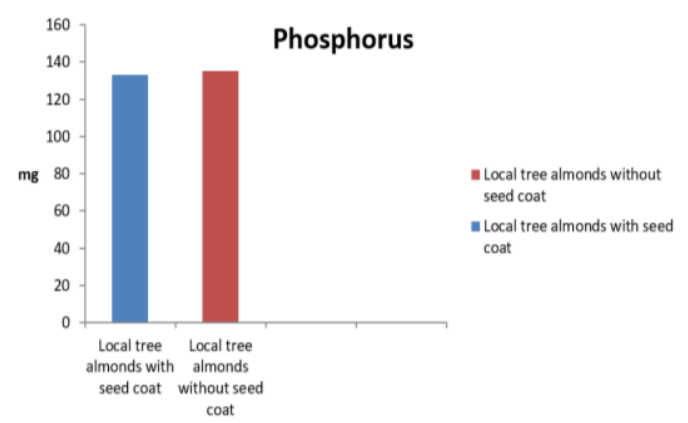

Figure 11. Phosphorous Content of Locally Collected $P$. amygdalus Seeds

Aslanta et al., 2001 found a high phosphorous content in $P$. amygdalus of $800.0 \mathrm{mg} / 100 \mathrm{~g}$. Seham et al., 2014 reported that $P$. amygdalus contains 0.53 $\mathrm{mg} / \mathrm{kg}$ of phosphorous. Agunbiade and Olanlokun, 2006 reported that the Indian variety of almonds, when grown in Nigeria have $0.19 \%$ of phosphorous. Mikdat and Veysi,. 2017 reported that the phosphorous content of $P$. amygdalus grown in Mardin region is high, ranging from 562.53-701.93 $\mathrm{mg} / 100 \mathrm{gin}$ the nine different genotypes 
studied. Barbera et al., 1994 reported that two almond varieteis contained 253.00 and 259.00 $\mathrm{mg} / 100 \mathrm{~g}$ of phosphorous. Studies on the phosphorous content of almonds from Spain revealed the presence of $364.00 \mathrm{mg} / 100 \mathrm{~g}$ of phosphorous (Saura and Cafiellas, 1982).

\section{Calcium:}

Calcium is a vital nutrient that is an integral part of the skeletal system of the body. It is the most abundant mineral in the body, about $99 \%$ of calcium is found in bones and teeth. It is also involved in muscle contraction and release of hormones. Almonds are considered as the richest source of calcium. The proportion of total calcium derived from almonds ranges from 73-86 percent. The recommended dietary allowance of calcium for an adult is $600 \mathrm{mg}$ per day. The calcium content of local tree almonds is more when compared to processed almonds. The amount of calcium the almond samples was estimated by the procedure described by Raghu Ramulu et al., 1983 Calcium in local tree almonds with seedcoat was found to be $450 \mathrm{mg} / 100 \mathrm{~g}$ and 625 $\mathrm{mg} / 100 \mathrm{~g}$ in almonds without seed coat.

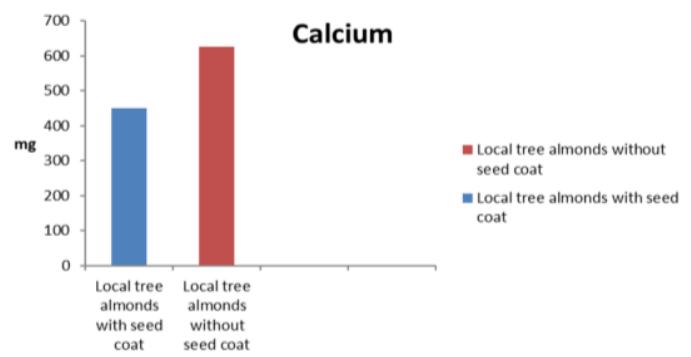

Figure 12. Calcium Content in P. amygdalus Seeda

The calcium content in P. amygdalus was found to vary between $98.5-187.0 \mathrm{mg} / 100 \mathrm{~g}$ (Aslanta et al., 2001). Saura and Cafiellas, 1982 evaluated the calcium content of almonds in Spain, and found it to be 218.00-299.00 $\mathrm{mg} / 100 \mathrm{~g}$, for different genotypes. A study on the almonds from the Middle East region revealed the presence of lower amounts of calcium, $0.23 \mathrm{mg} / \mathrm{kg}$ (Seham et al., 2014). The calcium content of Indian almonds growing in Nigeria was $845.45 \mathrm{ppm}$, estimated using an Atomic Absorption Spectrophotometer (Agunbiade and Olanlokun, 2006). The amount of calcium in almond milk was assessed by Alzoie et al., 2015 and found to be $13.10 \mathrm{mg} / 100 \mathrm{ml}$.

\section{Protein:}

The role of protein in the sustenance of the human body is undisputed. They form the major component of the tissues and muscles in the body. They are also involved in the production of hormones and enzymes. Though proteins are not a primary source of energy, they may serve as an alternate source of energy. A protein rich diet is critical for the health of an individual. Protein content in tree almonds was assayed using Lowry et al., 1951 method. Almonds were found to be rich in protein. The protein content was found to be more in local tree almonds without seed coat. The amount of protein in almond with seed coat is $43.2 \mathrm{~g} / 100 \mathrm{~g}$ and that of almonds without seed coat is $57.1 \mathrm{~g} / 100 \mathrm{~g}$. Almonds are an excellent choice for a high protein snack. Their protein is highly absorbable, making it easy for the body to process and use or store.

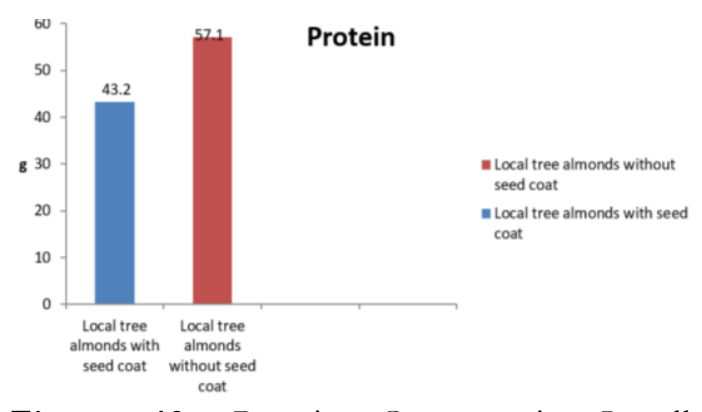

Figure 13. Protein Content in Locally Collected P. amygdalus Seeds

The crude protein of Indian almonds $(P$. amygdalus) grown in Nigeria was found to be $11.52 \%$ (Agunbiade and Olanlokun, 2006). A study by Seham et al., 2014 on P. amygdalus procured from the Middle East region revealed the presence of $22.83 \%$ of protein, suggesting that it can contribute to the daily protein need for adults as recommended by the Dietary Reference Intakes. Mikdat and Veysi,. 2017 reported the crude protein content of nine different genotypes of $P$. amygdalus from Mardin region to be $20.81-25.99 \%$. A study by Soler et al., 1989 revealed that the crude protein content in almond samples ranged from 18.00-25.00\%. Barbera et al., 1994 reported a protein content of $22.50-25.80 \%$. Susan et al., 2005 studied the protein content in three varieties of Californian almonds ( $P$. dulcis), which gave crude protein values of 20.6-23.3 g/100g. Alozie et al., 2015 studied the protein content in almond milk, which was found to be $1.70 \mathrm{~g} / 100 \mathrm{ml}$.

\section{Fiber:}

Dietary fiber is found abundantly in vegetables, fruits, legumes and nuts. It plays an important role in maintaining bowel health, helps control sugar level, lowers cholesterol level and helps in attaining healthy weight. The fiber content of the sample was determined by the method given by Raghu Ramulu et al., 1983. In local tree almonds, the nuts with seed coat had dietary fiber when compared to almonds without seed coat. The fiber content of locally collected $P$. amygdalus with seed coat was found to 
be $41.5 \mathrm{mg} / 100 \mathrm{~g}$ while that without seed coat was $32.0 \mathrm{mg} / 100 \mathrm{~g}$.

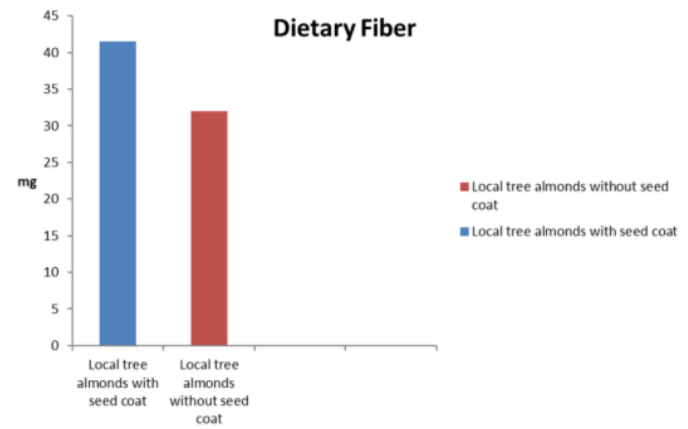

Figure 14. Dietary Fiber Content in Locally Collected P. amygdalus Seeds

A study by Agunbiade and Olanlokun, 2006 revealed the presence of $5.09 \%$ of crude fiber in $P$. amygdalus grown in Nigeria. A significant amount of crude fiber content was found in almond milk was found to be1.25 g/100ml, which was higher than that of soymilk, 0.70 $\mathrm{g} / 100 \mathrm{ml}$ (Alozie et al., 2015).

\section{Fat:}

Fat obtained from food is a vital component of the diet. Fats serve to provide the body with energy, play a key role in the absorption of fat-soluble vitamins, and make up the structural elements of cell walls. While a controlled intake of fats is essential for the well-being of the body, an increased intake is associated with several health complications, such as obesity, metabolic syndrome, coronary heart disease and cancer. The crude fat content in local almonds was estimated by the method given by Raghu Ramulu et al., 1983. Fat content in almonds with seed coat was found to be 20.5 $\mathrm{g} / 100 \mathrm{~g}$ and those without seed coat 46.0 $\mathrm{g} / 100 \mathrm{~g}$.

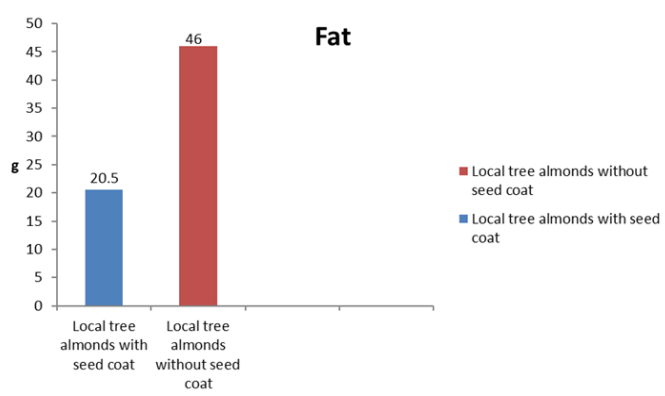

Figure 15. Fat Content in P. amygdalus Seeds

Nuts are a rich source of fat, but many studies have shown that fat in nuts is absorbed very poorly. The fat in almonds is located inside the almond cells. Even after prolonged chewing, most of the almond cells remained intact, and fat was still inside the almond cells. These results are in accordance with other studies carried out on different varieties of almonds.
Simsek and Demikiran, 2010 previously reported the crude fat content in different varieties of almonds ranging from 43.5054.81\%. Ozcan et al., 2011 reported the crude fat levels in almonds to be 48.80-55.70\%. Agar et al., 1997 reported that almonds contain $52.08-57.49 \%$ fat. The crude oil content in thirteen different varieties of $P$. amygdalus $\mathrm{L}$. from Turkey was found to 48.93-55.96\% (Mikdat and Veysi, 2017). Seham et al., 2014 reported $52.083 \%$ of crude fat in almonds from the Middle East region. Almond milk was found to possess $3.40 \mathrm{~g} / 100 \mathrm{ml}$, which did not differ significantly with that of soymilk, 3.20 g/100ml (Alozie et al., 2015).

\section{Conclusion}

Nuts (tree nuts and peanuts) are nutrient dense foods with complex matrices rich in unsaturated fatty and other bioactive compounds: high-quality vegetable protein, fiber, minerals, tocopherols, phytosterols, and phenolic compounds. By virtue of their unique composition, nuts are likely to beneficially impact health outcomes (Emilio, 2010). The most popular edible tree nuts are almonds, Prunus amygdalus. Almonds can improve human health when consumed in small $(10 \mathrm{~g} /$ day $)$ or large portions (100 g/day) (Ravila et al., 2017). There have been various studies which examined the health benefits of almond intake in the fields of weight management, heart health, and diabetes. One of major results from the previous almonds studies might be improvement of blood lipid profiles, including the levels of triglycerides, total cholesterol, low-density lipoprotein (LDL) cholesterol, and high-density lipoprotein (HDL) cholesterol particularly among subjects with dietrelated clinical symptoms such as obesity, diabetes, and hyperlipidemia (Liu et al., 2017). In addition to providing a good source of dietary fiber, almonds are also rich in unsaturated fatty acids. Unsaturated fatty acids, as opposed to saturated fatty acids, have been shown to have antimicrobial properties through the inhibition of bacterial fatty acid synthesis and growth, and also reduce microbial adhesion to mucus (Hannah et al., 2018).

Almonds have been a part of the traditional Indian diet since time immemorial and have been a part of several Indian cuisines. Traditionally, almonds in India are soaked and peeled to be eaten early in the morning and has had several positive connotations with respect to health (Kalita et al., 2018). Claire et al., 2015 suggest that a daily consumption of almonds (1.5 oz.) may be a simple dietary strategy to help prevent the onset of cardiometabolic diseases in healthy individuals. All the above studies demonstrate that there are multiple health benefits which may be attained by consumption of almonds on a regular basis. 
The proximate composition of locally available tree almonds, Prunus amygdalus was studied. Eight parameters were selected; moisture content, ash value, iron, phosphorous, calcium, protein, fat and fiber levels and were estimated by standard protocols. The findings of this study were in line with previous studies. Locally available $P$. amygdalus were found to have high amounts of protein, fat, calcium and phosphorous. While the fiber content was moderate, the amount of iron is considerably low, and the moisture and ash content were also low. The results obtained were in agreement with previously described studies. This makes locally available almonds a suitable, accessible and vital part of the diet.

\section{Acknowledgements}

The authors wish to thank Andhra University for the facilities provided.

\section{Conflict of Interest}

The authors declare that there is no conflict of interest.

\section{References}

1. Adriana A, Bisignano C, The Immunomodulatory and the Antiviral Activities of Almonds, Immunology Letters, 2010, 132 (1-2), 18-23.

2. Agar IT, Kafkas S, Kaska N, Effect of cold Storage on the Kernel Fatty Acid Composition of Almonds, Acta Horticulturae, 1997, 470, 349-358.

3. Agunbiade SO, Olanlokun JO, Evaluation of Some Nutritional Characteristics of Indian Almond (Prunus amygdalus) Nut, Pakistan Journal of Nutrition, 2006, 5(4), 316-318

4. Alozie YE, Udofia, Ukpong S, Nutritional and Sensory Properties of Almond (Prunus amygdalu Var. Dulcis) Seed Milk, World Journal of Dairy \& Food Sciences, 2015, 10(2), 117-121.

5. AOAC, Official Methods of Analysis, 16 th Edition, Association of Official Analytical Chemists, Arlington, VA, 1995.

6. Aslanta R, Guleryuz M, Turan M, Some Chemical Contents of Selected Almond (Prunus amygdalus Batsch) Types, Cahiers Options Mediterraneennes, 2001, 56, 347-350.

7. Barbera GL, Di MM, Schirra M, Effects of Rootstock on Productive and Qualitative Response of Two Almond Varieties, Acta Horticulturae, 1994, 373, 129-134.

8. Chen CY, Karen L, Jeffrey B, Perspective A Nutrition and Health Perspective on Almonds, Journal of the Science of Food and Agriculture, 2006, $86,2245-2250$.

9. Clarie EB, West SW, Fleming JA, Peter LB, Penny MKE, Effects of Daily Almond Consumption on Cardiometabolic Risk and Abdomonial Adiposity in
Healthy Adults with Elevated LDL-Cholesterol: A Randomized Controlled Trial, Journal of the American Heart Association, 2015, 4(1).

10. Emilio R, Health Benefits of Nut Consumption, Nutrients, 2010, 2, 652-682.

11. Fiske $\mathrm{CH}$, Subbarow $\mathrm{Y}$, The Colorimetric Determination of Phosphorous, Journal of Biological Chemistry, 1925, L16(2), 375-400.

12. Gary RT, Lan TD, Antioxidant Constituents of Almond [Prunus dulcis (Mill.) D. A. Webb] Hulls, Journal of Agricultural and Food Chemistry, 2003, 51, 496-501.

13. Hannah DH, Andrew MT, Kelly SS, Janet AN, David JB, Almond Consumption and Processing Affects the Composition of the Gastrointestinal Microbiota of Healthy Adult Men and Women: A Randomized Controlled Trial, Nutrients, 2018, 10(2), 126.

14. Hari JR, Lakshmi, Therapeutic Applications of Almonds (Prunus amygdalus L): A Review, Journal of Clinical and Diagnostic Research, 2012, 6(1), 130135.

15. Kalita S, Shweta K, Madan J, Pandaya H, Sesikeran B, Kamala K, Almonds and Cardiovascular Health: A Review, Nutrients, 2018, 10(4), 468.

16. Kulkarni KS, Kastura SB, Mengi SA, Efficacy of the Prunus amygdalus (Almonds) Nuts in Scopolamineinduced Amnesia in Rats, Indian Journal of Pharmacology, 2010, 48, 168-173.

17. Liu Y, Hwang HJ, Ryu H, Lee YS, Kim HS, Park H, The effects of Daily Intake Timing of Almond on the Body Composition and Blood Lipid Profile of Healthy Adults, Nutrition Research and Practice, 2017, 11(6), 479-486.

18. Lowry OH, Rosebrough NJ, Farr AL, Randall RJ, Protein Measurement with the Folin Phenol Reagent, Journal of Biological Chemistry, 1951, 193, 265-275.

19. Mandalari G, Neuno-palop C, Bigignano G, Wickham MSJ, NArbad A, Potential Prebiotic Properties of Almond Seeds, Journal of Applied and Environmental Microbiology, 2008, 74(14), 42644270.

20. Mikdat S, Veysi K, Determination of Chemical and Mineral Compositions of Promising Almond (Prunus amygdalus L.) Genotypes from Beyazsu (Mardin) Region, International Journal of Agriculture and Life Science, 2017, 3(1), 6-11.

21. Omole JO, Ighodaro OM, Proximate Composition and Quality Attributes of Milk Substitute from Melon Seeds (Citrulus vulgaris schrad), Report and Opinion, 2012, 4(9), 75-78.

22. Ozcan MM, Unver A, Erkan E, Arslan D, Characterstics of Some Almond Kernel and Oils, Scientia Horticulturae, 2011, 127, 330-333. 
23. Passmore R, Eastwood WA, Human Nutrition and Dietetics, $8^{\text {th }}$ Edition, Churchhill Livingstone, 1986, 239-240.

24. Potter NN, Hotchkiss JH, Food Science, $5^{\text {th }}$ Edition, Chapman and Hall, 1995, 315.

25. Raghuramulu N, Nair MK, Kalyan SS, A Manual of laboratory Techniques, $1^{\text {st }}$ Edition, National Institute of Nutrition-ICMR, Hyderabad, India, 1983, 178179.

26. Ravila GMS, Raquel MS, Gustavo DP, Mota JF, Nuts and Human Health Outcomes: A Systematic Review, Nutrients, 2017, 9(12), 1311.

27. Richardson DP, Arne A, Arnaud C, Peter E, The Nutritional and Health Benefits of Almonds: A Healthy Food Choice, Food Science and Technology Bulletin: Functional Foods, 2009, 6(4), 41-50.

28. Ryszard A, Agnieszka T, Freleidoon S, Antioxidant Activity of Almond Seed Extract and its Fractions, Journal of Food Lipids, 2005, 12 (4), 344-358.

29. Saura CF, Cafiellas J, Mineral Composition of Almond Varieties (Prunus amygdalus L.), Zeitschrift fur Lebensmittel-Untersuchung undForschung, 1982, 174, 129-131.

30. Sathe SK, Wolf WJ, Roux KH, Tueber SS, Venkatchalam M, Sze TKWC, Biochemical Characterization of Amandin, the Major Storage Protein in Almond (Prunus dulcis L.), Journal of Agricultural and Food Chemistry, 2002, 50, 4333 4341.
31. Seham SHE, Nadia MS, Ali MH, Helmi AM, Study of Nutritional Contents of Prunus amygdalus Batsch Seeds, The Egyptian Journal of Hospital Medicine, 2014, 57, 437-443.

32. Simsek M, Demikiran AR, Determination of Superior Almond Genotypes in Deyarbakir central Districts, Agricultural Journals, 2010, 5, 173-180.

33. Soler L, Canellas J, Calixto F, Changes in Carbohydrate and Protein content and Composition of Developing Almond Seeds, Journal of Agricultural Food chemistry, 1989, 37, 1400-1404.

34. Subhashinee SKW, Ryszard A, Fereidoon S, Antioxidant Activity of Almonds and their Byproducts in Food Model Systems, Journal of the American Oil Chemists' Society, 2006, 83 (223).

35. Susan A, Mahesh V, Anahita MM, Karen L, Shridhar KS, Almond (Prunus dulcis L.) Protein Quality, Plant Foods for Human Nutrition, 2005, 60, 123-128.

36. Venkatchalam M, Tueber SS, Roux KH, Sathe SK, Effects of roasting, Blanching, Autoclaving and Microwave Heating on Antigenicity of Almond (Prunus dulcis L.) Proteins, Journal of Agricultural and Food Chemistry, 2002, 50, 3544-3548.

37. Wong SY, Colorimetric Determination of Iron of Iron and Hemoglobin in Blood II, Journal of Biological Chemistry, 1928, 77, 409-412.

\section{Cite this article as:}

Pola Sudhakar, Priyanka K., Angela E. Peter, B. V. Sandeep, M. Rajeswari, B. Ganga Rao, P. Sujatha. A study on the proximate composition and nutritive value of local tree almonds, Prunus amygdalus. Annals of Plant Sciences 7.6 (2018) pp. 2363-2372.

do $\mathrm{http}$ ///dx.doi.org/10.21746/aps.2018.7.6.13

Source of support: Andhra University Conflict of interest: Nil 